\title{
EKSISTENSI GURU DALAM PENANAMAN NILAI PENDIDIKAN ISLAM MULTIKULTURAL DI ERA MILENIAL
}

\author{
ALI AKBARJONO
}

\begin{abstract}
The existence of Teachers at schools is important in implementing the values of inclusive diversity in today's modern world and plays a vital role in educating the values of social politeness, tolerance and mutual respect for generation $z$ in this milineal era. The teacher has an important role in multicultural education because he is one of the targets of the education strategy in the literature on understanding humanist, dialogical-persuasive, contextual, substantive and socially active. Paradigm about the urgency of teachers to teach and implement the values of diversity in schools, teachers have an important role in fostering students' social care attitudes, among others; (a) A teacher should have sufficient insight that multicultural Islamic education is essentially education that places multiculturalism as one of the visions of education with the main characters who are inclusive, egalitarian and humanist, but still firm in spiritual and divine values based on al Qur'an and Sunnah; (b) Teachers should have sensitivity to discrimination and social, economic and political key justice that is happening; (c) The teacher must directly apply the anti-discriminatory, social, political and economic attitudes in the classroom; (d) The teacher does not discriminate between the students' children, officials and students of pedicab drivers, all are treated equally.
\end{abstract}

Kata Kunci: Eksistensi Guru, Pendidikan Islam

\section{A. Pendahuluan}

Seiring dengan laju perjalanan waktu yang begitu deras saat ini berimplikasi pada perkembangan peradaban manusia, ditandai adanya perkembangan ilmu pengetahuan dan tehnologi diistilahkan era Industri 4.0, serba digitalisasi dan otomasi. Namun tak terpungkiri ternyata belum semua elemen masyarakat menyadari konsekuensi logis atau dampak dari perubahan-perubahan yang ditimbulkannya. Bahkan, fakta-fakta perubahan itu masih sering diperdebatkan. Misalnyaarus globalisasi dan efek sosial yang terjadi dalam kehidupan masyarakat dewasa ini. Budaya global dan gaya hidup (life 
style) merupakan dampak paling kentara akibat fenomena multikulturalisme.

Multikulturalisme adalah proses pembudayaan. Pendidikan multicultural adalah adalah strategi pendidikan yang diaplikasikan pada semua jenis mata pelajaran dengan cara menggunakan perbedaan-perbedaan kultural yang ada pada para siswa seperti perbedaan etnis agama, bahasa, gender, khas sosial, ras, kemampuan, dan umur agar proses belajar menjadi efektif dan mudah ${ }^{1}$

Dengan adanya keberagaman dan perbedaan kultural ini rentan terjadinya perselisihan dalam interaksi di lingkungan baik sekolah maupun masyarakat luas. Namun hal ini bisa menjadi permasalahan ketika mereka tidak menerima perbedaan- perbedaan itumeski mereka berasal dari daerah pada peserta didik yang berbedabeda dengan beragam kultur dan bahkan berbedaa gama mereka bisa menjaga hubungan baik di lingkungan sekolah, walaupun secara kultural terdapat perbedaan antar warga sekolah. Hal tersebut tidak terlepas dari peran guru-guru di sekolah tersebut di dalam melaksanakan tugasnya demi terciptanya suasana multikultural, khususnya bagi guru yang sebagai agama mayoritas dengan pemeluk terbanyak disekolah tersebut.

Oleh karena itu, guru dalam Pendidikan Islam dituntut tanggap terhadap berbagai kondisi dan perkembangan yang terdapat di lembaga tersebut serta memahami keberagaman seluruh anggota warga sekolah. Sejatinya dalam beberapa dekade belakangan ini, gagasan yang berupaya mengakomodasi dan menata aspek keragaman melalui agenda pendidikan Islam cukup banyak dilakukan. Tidak sedikit pula ide-ide bermunculan terkait multikulturalisme yang teraktualisasi dalam wacana pendidikan Islam $^{2}$. 
Menapaki fenomena globalisasi yang berimplikasi pada sistem peradaban masyarakat modern di era milenial saat ini terutama di negeri yang konon memiliki kekayaan budaya, berbagai macam adatistiadat dengan beragam ras, suku bangsa, agama dan kaya akan bahasa itulah bangsa Indonesia.

Indonesia adalah salah satu negara multikultural terbesar di dunia karena terkenal dengan kekayaan dan keanekaragaman agama,etnikdankebudayaan,ibaratpisaubermatadua.Disatusisikekaya an ini merupakan khazanah yang patut dipelihara dan memberikan nuansa dan dinamika bagi bangsa, dan dapat pula merupakan titik pangkal perselisihan, konflik vertikal dan horizontal.

Disamping itu kondisi sosial generasi muda (generasi Z) saat ini juga menunjukkan sydrom kegalauan dalam sikap dan moralitas akibat dari dinamika dan perkembangan peradaban modern bisa dikatakan kian kompleks. berkat kemudahan akses informasi yang ditopang internet dan media sosial ibarat dua sisi mata uang. Di satu sisi bisa menumbuhkan iklim kreatif dan semakin luasnya pengetahuan, tapi di sisi lain, berpotensi menyebabkan dekadensi moral dan spiritual.

Menyikapi fenomena ini,pendidikan yang di dalamnya ada gurumempunyai peran penting dalam membentuk kehidupan generasi muda, selain itu juga diyakini mampu memainkan peranan yang signifikan dalam membentuk politik dan kultural. Dengan demikian pendidikan sebagai media untuk menyiapkan dan membentuk kehidupan sosial, sehingga akan menjadi basis institusi pendidikan yang sarat akan nilai-nilai idealisme.

Seiring perjalanan waktu dan perkembangan zaman seperti saat ini proses pengembangan serta aspek implementasi keberagaman dalam budaya dan pemikiran masih belum berjalan sesuai harapan. 
Pelaksanaan pendidikan Islam multikultural masih dihadapkan pada berbagai macam persoalan.Sebagai wacana yang relatif baru, hal ini tentu saja bisa dimaklumi. Akan tetapi, apabila dikaitkan dengan fenomena yang terjadi dan berbagai persoalan yang ada di lapangan, kebutuhan akan implementasi yang tepat dan terarah, merupakan hal yang mendesak untuk dilakukan pencarian solusi dan pemecahan permasalahan yang berhubungan dengan konteks multikulturalisme.

\section{B. Pendidikan Islam Multikultural di SEKolah}

Guru merupakan faktor penting dalam mengimplementasikan nilai-nilai keberagamaan yang inklusif dan moderat di persekolahan, karena seorang guru yang memiliki paradigma pemahaman keberagamaan yang moderat akan mampu untuk mengajarkan dan mengimplementasikan nilai-nilai keberagaman tersebut kepada peserta didik di sekolah.

Pendidikan agama khususnya pendidikan agama Islam diharapkan mampu mengubah pemahaman dan penghayatan keislaman masyarakat muslim Indonesia secara khusus dan masyarakat beragama pada umumnya. Sikap exclusivisme perlu diubah menjadi universalisme, dengan harapan dapat melahirkan suatu generasi yang siap hidup toleran (tasamuh) dalam wacana multikultiralisme sehingga tidak melahirkan masyarakat yang ekstrim, yang kurang mampu menghargai perbedaan dan toleransi antar sesama.

Pendidikan agama Islam yang diberikan baik di sekolah-sekolah, madrasah-madrasah maupun di pesantren-pesantren, hendaknya terintegrasi dengan spirit pendidikan multikultural ini. Oleh karena itu, dalam pengembangan kurikulum PAI masa depan dengan yang berwawasan multikultural haruslah didasarkan pada prinsip-prinsip berikut; a). Keragaman budaya menjadi dasar dalam menentukan filsafat, 
teori, model, dan hubungan sekolah dengan lingkungan sosial-budaya setempat; b) Keragaman budaya menjadi dasar dalam mengembangkan berbagai komponen kurikulum seperti tujuan, konten, proses dan evaluasi; c) Budaya di lingkungan unit pendidikan adalah sumber belajar dan objek studi yang harus dijadikan bagian dari kegiatan anak didik, dan d) Kurikulum berperan sebagai media dalam mengembangkan kebudayaan daerah dan kebudayaan nasional.

Pendidikan agama Islam melalui ajaran akidahnya, perlu menekankan pentingnya persaudaraan umat beragama.Pelajaran akidah, bukan sekedar menuntut pada setiap peserta didik untuk menghapal sejumlah materi yang berkaitan denganya, seperti iman kepada Allah Swt., Nabi Muhamad Saw., dan lain-lain.Tetapi sekaligus juga menekankan arti pentingya penghayatan keimanan tadi dalam kehidupan sehari-hari.Intinya, akidah harus berbuntut dengan amal perbuatan yang baik atau akhlak al-karimah pada peserta didik.Memiliki akhlak yang baik pada Tuhan, alam dan sesama umat manusia.

Pendidikan Islam harus sadar, bahwa kerusuhan-kerusuhan bernuansa SARA seperti yang sering terjadi di Indonesia ini adalah akibat ekspresi keberagamaan yang salah dalam masyarakat kita, seperti ekspresi keberagamaan yang masih bersifat ekslusif dan monolitik serta fanatisme untuk memonopoli kebenaran secara keliru.Celakanya, ekspresi keagamaan seperti itu merupakan hasil dari pendidikan agama. Pendidikan agama dipandang masih banyak memproduk manusia yang memandang golongan lain (tidak seakidah) sebagai musuh. Maka di sinilah perlunya menampilkan pendidikan agama yang fokusnya adalah bukan semata kemampuan ritual dan keyakinan tauhid, melainkan juga akhlak sosial dan kemanusiaan.

Pendidikan agama, merupakan sarana yang sangat efektif untuk menginternalisasi nilai-nilai atau akidah inklusif pada peserta 
didik.Perbedaan agama di antara peserta didik bukanlah menjadi penghalang untuk bisa bergaul dan bersosialisasi diri. Justru pendidikan agama dengan peserta didik berbeda agama, dapat dijadikan sarana untuk menggali dan menemukan nilai-nilai keagamaan pada agamanya masing-masing sekaligus dapat mengenal tradisi agama orang lain. Target kurikulum agama Islam harus berorientasi pada akhlak. Dalam persoalan syariah, sering umat Islam juga berbeda pendapat dan bertengkar.Maka dalam hal ini pendidikan Islam perlu memberikan pelajaran fiqih muqoron untuk memberikan penjelasan adanya perbedaan pendapat dalam Islam dan semua pendapat itu sama-sama memiliki argumen, dan wajib bagi kita untuk menghormati.Sekolah tidak menentukan salah satu mazhab yang harus diikuti oleh peseta didik, pilihan mazhab terserah kepada mereka masing-masing.

Melalui suasana pendidikan seperti itu, tentu saja akan terbangun suasana saling menenami dalam kehidupan beragama secara dewasa, tidak ada perbedaan yang berarti diantara perbedaan manusia yang pada realitasnya memang berbeda. Tidak dikenal superior ataupun inferior, serta memungkinkan terbentuknya suasana dialog yang memiliki peluang untuk membuka wawasan spritualitas baru tentang keagamaan dan keimanan masing-masing.

Pendidikan Islam harus memandang iman, yang dimiliki oleh setiap pemeluk agama, bersifat dialogis artinya iman itu bisa didialogkan antara Tuhan dan manusia dan antara sesama manusia.Iman merupakan pengalaman kemanusiaan ketika berintim dengan-Nya (dengan begitu, bahwa yang menghayati dan menyakini iman itu adalah manusia, dan bukannya Tuhan), dan pada tingkat tertentu iman itu bisa didialogkan oleh manusia, antarsesama manusia dan dengan menggunakan bahasa manusia. 
Tujuan untuk menumbuhkan saling menghormati kepada semua manusia yang memiliki iman berbeda atau mazhab berbeda dalam beragama, salah satunya bisa diajarkan lewat pendidikan akidah yang inklusif. Dalam pembelajarannya, tentu saja memberikan perbandingan dengan akidah yang dimiliki oleh agama lain (perbandingan agama). Pengajaran agama seperti itu, sekaligus menuntut untuk bersikap objektif sekaligus subjektif.Objektif, maksudnya sadar bahwa membicarakan banyak iman secara fair itu tanpa harus meminta pertanyaan mengenai benar atau validnya suatu agama. Subjektif berarti sadar bahwa pengajaran seperti itu sifatnya hanyalah untuk mengantarkan setiap peserta didik memahami dan merasakan sejauh mana keimanan tentang suatu agama itu dapat dirasakan oleh orang yang mempercayainya. ${ }^{12}$

\section{KESIMPULAN}

1. Guru merupakan ujung tombak dari pengembangan pendidikan multikultural. Peran guru sangat menentukan dalam keberhasilan mendorong pemahaman lintas budaya pada peserta didik. Apa yang disampaikan guru, cara guru mengajar, dan kepribadian guru sangat mempengaruhi keberhasilan pembelajaran

2. Eksistensi guru dalam pengembangan pendidikan multikultural meliputi beberapa hal, yaitu: Pertama, seorang guru/dosen harus mampu bersikap demokratis, baik dalam sikap maupun perkataannya tidak diskriminatif. Kedua, guru/dosen seharusnya mempunyai kepedulian yang tinggi terhadap kejadian-kejadian tertentu yang ada hubungannya dengan agama.

3. Pendidikan multikultural sesungguhnya hingga saat ini belum begitu jelas dan mash banyak pakar pendidikan yang memperdebatkannya. 
4. Secara umum, peran guru dalam menerapkan pendidikan Islam Multikultural telah sesuai dengan maksud dan tujuan pendidikan Islam multikultural.

Penulis : Dr. H. Ali Akbarjono, M.Pd (alikbarj250975@gmail.com) adalah Dosen Tetap pada Fakultas Tarbiyah dan Tadris IAIN Bengkulu

\section{DAFTAR PUSTAKA}

Abdul Kodir, Sejarah Pendidikan Islam, (Bandung: Pustaka Setia), 2015, h.86

Agus Nuryatno, M. Mazhab Pendidikan Kritis Menyingkap Relasi Pengetahuan,

Ainun, Hakiemah, "Nilai-nilai dan Konsep Pendidikan Multikultural dalam Pendidikan Islam", Tesis, Yogyakarta: UIN Sunan Kalijaga, 2007

Akhmad Hidayatulloh Al Arifin, Implementasi Pendidikan Mutikultural dalam Praktis Pendidikan di Indonesia, Jurnal Pengembangan Pendidikan Fondasi dan Aplikasi , Vol.1 No.1 Juni 2012.

AM., Sardiman, Interaksi dan Motivasi Belajar Mangajar, Jakarta: Raja Grafindo Persada, 1996

Baidhawy, Zakiyuddin, Pendidikan Agama Berwawasan Multikultural, Jakarta: PT. Gelora Aksara Pratama. 2005

Choirul Mahfud, Pendidikan Multikultural, (Yogyakarta: Pustaka Pelajar), 2008.h. 196-198

H. A. R. Tilaar, Multikulturalisme Tantangan-tantangan Global Masa Depan Dalam Transformasi Pendidikan Nasional (Jakarta: PT. Grafindo), 2004, hal. 27

Hakiemah, Ainun, “Nilai-nilai dan Konsep Pendidikan Multikultural dalam Pendidikan Islam", (Tesis,Yogyakarta: UIN Sunan Kalijaga), 2007, h.46 
Iqbal awal.2018. 3 Elemen Pendidikan yang Diperlukan Generasi Millennial Indonesia. artikel kumparan diakses dari https://kumparan.com/iqbal-awal/3-elemen-pendidikan-yangdiperlukan-generasi-millenial-indonesia

Kamus Besar Bahasa Indonesia Terbitan Departemen Pendidikan Kebudayaan (Balai Pustaka) hal. 11

Kodir, Abdul, Sejarah Pendidikan Islam, Bandung: Pustaka Setia, 2015

M. Agus Nuryatno, Mazhab Pendidikan Kritis Menyingkap Relasi Pengetahuan, Politik dan Kekuasaan, (Yogyakarta: Resist Book), 2008, h. 90

M. Ainul Yaqin, Pendidikan Multikultural, Cross Cultural Undersatanding untuk Demokrasi dan Keadilan. (Yogyakarta: Pilar Media, 2005), hlm. 25.

Murtiningsih, Siti, Pendidikan Alat Perlawanan; Teori Pendidikan RadikalPaulo Freire, Yogyakarta: Resist Book, 2004

Naim, Ngainum dan Ahmad Syauqi, Pendidikan Multikultural: Konsep dan Aplikasi, (Jogjakarta: Ar-Ruzz Media), 2008, h. 56

Nana Syaodih Sukmadinata, Pengembangan Kurikulum dan Praktek, (Bandung: Remaja Rosdakarya, 1999), hal. 61.

Ngainum, Naim,dkk. Pendidikan Multikultural: Konsep dan Aplikasi, Jogjakarta: Ar-Ruzz Media, 2008

Nganggung,P. Paul, SVD, "Pendidikan Agama Dalam Masyarakat Pluralistik", dalam Sumartana dkk, Pluralisme, Konflik Dan Pendidikan Agama di Indonesia,Yogyakarta: Pustaka Pelajar, cet.II, 2005

Nurani Soyomukti, Pendidikan Berperspektif Globalisasi (Yogyakarta: Ar-Ruzz Media, 2008) h, 76

Nuryatno,M. Agus, Mazhab Pendidikan Kritis Menyingkap Relasi Pengetahuan, Politik dan Kekuasaan, Yogyakarta: Resist Book, 2008 
P. Paul Nganggung, SVD, "Pendidikan Agama Dalam Masyarakat Pluralistik", dalam Sumartana dkk, Pluralisme, Konflik Dan Pendidikan Agama di Indonesia (Yogyakarta: Pustaka Pelajar, cet.II, 2005), hal. 259

QS. al-Baqarah: 30, QS. an-Nur: 55, QS. Al-Imran: 26, QS. al-An'am: 165, QS.

Raharjo, Turnomo, Menghargai Perbedaan Kultural, Yogyakarta: Pustaka Pelajar,

Siti Murtiningsih, Pendidikan Alat Perlawanan; Teori Pendidikan RadikalPaulo Freire, (Yogyakarta: Resist Book), 2004, h. 62

Sudiardja, "Filsafat Pendidikan Paulo Freire", dalam, "Bunga Rampai SudutSudut Filsafat" Yogyakarta: Yayasan Kanisius, 1977

Sukmadinata,Nana Syaodih, Pengembangan Kurikulum dan Praktek, Bandung: Remaja Rosdakarya, 1999

UU RI No. 14 Tahun 2005 Tentang Guru dan Dosen (Bandung: CV. Citra Umbara) hal.

UU RI No.20 Tahun 2003, Tentang Sistem Pendidikan Nasional (Jakarta: Sinar Grafika), 2006

Zakiyuddin Baidhawy, Pendidikan Agama Berwawasan Multikultural (Jakarta: PT. Gelora Aksara Pratama, 2005), h. 21

Zuhairi dkk.,Metodik Khusus Pendidikan Agama, Surabaya: Usaha Nasional, 1983.

${ }^{1}$ M. Ainul Yaqin, Pendidikan Multikultural, Cross Cultural Undersatanding untuk Demokrasi dan Keadilan. (Yogyakarta: Pilar Media, 2005), hlm. 25.

${ }^{2}$ M. Agus Nuryatno, Mazhab Pendidikan Kritis Menyingkap Relasi Pengetahuan, Politik, dan Kekuasaan (Yogyakarta: Resist Book), 2008, h. 81

12 Muhaimin dkk., Paradigma Pendidikan Islam; Upaya Mengefektifkan Pendidikan Agama di Sekolah, (Bandung: Remaja Rosdakarya), 2002, h 83 